\title{
SOCIAL MEDIA NETWORKING OF MICRO ENTREPRENEURS AND PERFORMANCE OF AGENT BANKS
}

\author{
${ }^{1}$ Timinepere Ogele Court ${ }^{*}$, Alaowei Kingsley Appiah ${ }^{2}$ \& Joseph Esoghene Isikuru ${ }^{3}$ \\ ${ }^{1}$ Department of Business Administration, University of Africa, Toru- Orua, Nigeria \\ ${ }^{2}$ Department of Business Education, Isaac Jasper Boro College of Education, Sagbama, \\ Nigeria \\ ${ }^{3}$ Department of Management, University of Nigeria, Enugu Campus, Enugu, Nigeria \\ *Corresponding Author's Email: timi2k2002@gmail.com, timinepere.court@uat.edu.ng \\ Phone +234(0)8066933764
}

\begin{abstract}
There is a large body of literature in social media, agent banking and entrepreneurship in disparate and fragmented forms. The nexus between social media platforms for entrepreneurial networking and performance in the context of agent banking remains underexplored. To address this knowledge gap, this paper investigates social media platforms for networking by micro entrepreneurs and performance of agent banks in Nigeria. Analytic descriptive survey design is adopted in the study while a sample of 150 agent banks are selected by employing simple random and cluster sampling procedures. Data were collected from self reports of micro entrepreneurs of agent banks with the use of questionnaire. Data collected were analysed with frequency counts, percentage distribution, logistic regression and analysis of variance. The results demonstrated that micro entrepreneurs of agent banks utilize social media platforms to initiate formal and informal ties to improve business performance. The paper concludes that quite a number of micro entrepreneur agents of banks network with social media platforms but some bank agents do not network with a view to establishing formal and informal ties for business purposes.
\end{abstract}

Keywords: Social Media, Networking, Micro Entrepreneurs, Agent banking, Performance, Nigeria. 


\section{Introduction}

Over the past decade, there is a growing interest in the use of social media by individuals, micro entrepreneurs and corporate bodies to communicate, exchange information and resources, which is ubiquitous and on the ascendency (McCann and Barlow, 2015; Jussila, Karkkainen, and Aramolo-Immonen, 2014, Helmond, Nieborg and Van der Vlist, 2019). Accordingly, firms, micro entrepreneurs and individuals initiate relationships with other firms, agencies, governments to foster entrepreneurial activities and this process is sped up through the instrumentality of digital globalization (Christmann and Taylor, 2002). The necessity for firms and individuals in striking relationship with external bodies, agencies and other individuals is to seek support and resources to enable them enhance performance and realize business goals; and to establish relations with external bodies for support is referred to as networks (Urban, 2019).

Das and Goswami (2019) state that entrepreneurial network refers to entrepreneurs and entrepreneurial firms that coalesce and facilitate efficiency of member business activities through formal or informal ties with individuals and organizations. Accordingly, Gulati, Nohria and Zaheer(2000) assert that strategic networks enable firms and entrepreneurial entities to gain access to markets, useful information, technologies and acquisition of resources, and no doubt these are critical success factors to entrepreneurial activities, sustainable entrepreneurial development and performance.

There is multitude of research evidence in the domains of globalization (e.g. Ayenagbo, Rongcheng, Wengjing, Nguchi, Kimatu and Patrick, 2013; Mukherjee, 2018), entrepreneurship (e.g. Chen, Fu, Wang, Tsai and Su, 2018), globalization and entrepreneurship (e.g Vinig \& Kluijver, 2007; Petrova, 2013), the use of social media for networking (Kahar, Yamimi, Bunari and Habil, 2012; Yang, Cao, Andrikopoulou, Yan and Bass, 2020; Sayham, Datta, Brooks, 2019; Smith, Smith and Shaw, 2017). However, research scholarship on the use of social media for entrepreneurial networking is sparse and fragmented with unresolved and disparate findings (Olanrewaju, Hossain, Whiteside and Mercieca, 2020), and in the context of Nigeria and agency banking, there seems to be dearth of scientific scholarship and no adequate research attention directed to ascertain the use of social media platforms and networking to establish ties as well as the effect on the performance of agents banking firms. Accordingly, this paper is to bridge the knowledge vacuum by contributing to the existing body of literature.

The paper aims to examine the use of social media platforms by micro entrepreneurs of agent banks to establish formal and informal business ties; and ascertain performance level of agent banks for utilizing social media platforms. Thus, the structure of the paper is to review conceptual and empirical literature, theory and hypothesis development, methodology, data analysis and results, discussion and conclusion, and direction for future studies.

\section{Literature Review}

\subsection{Micro entrepreneurs in the context of agent banking firms}

Bayelsa state with a total land area of $9,059 \mathrm{~km}^{2}$ is located in the Southern part of Nigeria and it is the core of the Niger Delta, predominantly surrounded by extensive body of water, water ways and rivers. The state was created on 1st October, 1996 by the Sani Abacha's Military Government and hitherto, it is deficient of good road networks connecting and crisscrossing the hinterland (Wikipedia, n.d). This circumstance creates a difficult terrain for accessing some of the local government headquarters and most rural communities and as a 
consequence, financial institutions are not also established in the rural areas. Besides, the state is one of the poorest. According to the National Bureau of Statistics (NBS, 2019), Bayelsa state is documented as 22.61 percent in poverty headcount rate and 5.25 percent in poverty gap index among the 36 states of the Federation in Nigeria.

The Nigerian national financial inclusion strategy was initiated and launched in 23 October, 2012 with a core mandate to address the poverty level, promote finical accessibility and attain all inclusive economic growth in all regions. The principal objective was reduction of Nigerian adults who do not have access to financial services from 46.3 percent to 20 percent by 2020(Central Bank of Nigeria [CBN], 2017). Financial inclusion is the development of financial system to provide financial services to millions of men and women especially in developing economies of the globe. Financial inclusion is a process or situation that promotes accessibility, availability and utilization of financial services through a formal financial system in an economy. It is intended to facilitate opening of bank account, access to credit and consistent use of financial products with ease, convenience and no difficulty ( $\mathrm{CBN}$, 2013; Abdulmumin, Etudaiye-Muhtav, Jimoh and Sakariyahu, 2019). The policy underscores the need for promoting saving culture among the population of the poor and discourages saving money at home and mitigates the risks associated with such financial culture. It is a grand strategy to stimulate inclusive growth which becomes the driving force for adoption of the policy framework and measures for reduction of poverty, income inequality and promote economic prosperity (CBN, 2013; Ibrahim, Odeser and Cavusoglu, 2018).

Over the years, the government, regulatory authorities and stakeholders made several efforts to bring about financial inclusion but the most recent step is provision of electronic banking products, payment system and the cashless policy leading to introduction of Automated Teller Machine (ATM), Point-of- Sale (POS), mobile money, internet and agent banking(CBN,2013, 2017). Agent banking as one among the strands of the financial inclusion policy framework is a recent predominant practice in Africa and it is growing exponentially in Nigeria. A survey statistics indicates that over 15 million, with an equivalent of $16 \%$, adults in Nigeria made digital payments for goods and services in a year and it is further documented that $2.6 \%$ in 2016 and $3.3 \%$ in 2018, with a growth rate of $6 \%$ within the period, represent banking agents in the total banking population of 36.6 million and 39.5 million people in 2016 and 2018 respectively in Nigeria (Margaret and Ruth, 2019; PatriciaNezianya and Izuchukwu, 2014; EFInA, 2018). For example, only First Bank of Nigeria PLC in March, 2019 has 22,000 bank agents across the country in 755 out of the 774 local government areas with over 10,000 locations and 98\% coverage in Nigeria (Ogunwusi, 2019). Thus, agent bank entrepreneurs bring financial services to the doorstep of the poor in rural and urban communities, and this overcomes the challenges associated traditional bank branch networks, realizes financial inclusion and stimulates inclusive growth.

Agent banking firms depend heavily on communication technology and internet connectivity to engage in and effect financial transactions at the turn of the twenty first century. Micro entrepreneurs of agent banking enterprises utilize mobile applications, mobile phones, point of sale (POS) systems and digital platforms in making transactions that reflect on the accounts of financial institutions without delay and make exchange in Nigeria. Bank agents are mobile networks and retail outlets which engage in a contractual agreement with financial institutions and process clients' transactions. Agent banking provides a number of services which includes cash withdrawals and deposits, funds transfers, utility and other bill 
payments, loan disbursements and payments, collections of accounts and loan applications and payments of benefits and salaries to clients (Uzoma, Ailemen, Olumriola, and Emena, 2016).

It is documented that circa $65.4 \%$ of the total population of Nigeria forms the internet user penetration rate while there are approximately 32.4 million users of social media network in 2020 of which 25.6 million users are facebook and 6.10 million users are of instagram in Nigeria(Statistica,2020; Napoleoncat, 2019), and this becomes a huge potential for micro entrepreneurs of agent banking firms for exploring, establishing ties and act as a bridge between individual customers and financial institutions. In addition, micro entrepreneur agents of banks can engage in networking with kinship, acquaintances and formal entities for the purpose of interchanging knowledge, information and resources with other owners of agent banking firms and transact business with suppliers, customers and prospects. In view of competitive intensity of the financial service industry, Dootson, Beatson and Drennan (2016) assert that banks adopt social media platforms as a two-way interactive communication tool to add value to customers. From their empirical evidence, the authors conclude that the application of social media translate into customer perception of usefulness value, economic value and which further influence customer intention to adopt social media as an alternative communication channel to interact with financial intermediaries.

\subsection{Social Media Platforms}

In view of technologies in communication through mobile phones and the internet connectivity, globalization process now assumes a digital dimension (Bowen, Green and James, 2008). Digital globalization is the application of communication technologies for connecting people, institutions, enterprises and nations across borders through multiple digital and media platforms which are created for social, educational, political, marketing and economic purposes (Cunningham, 2015).

Digital platform is considered as an ecosystem consisting partners of upstream suppliers and downstream buyers and complementors (De Falco, Renzi, Orlando and Cucari, 2017). Digital platform in technical view is "an extensible codebase to which third-party modules can be added" while in "socio technical term, it consist of "technical elements (of software and hardware) and associated organizational processes and standards" (Reuver, Sorensen and Basole, 2018: 127). Examples of platforms and platform providers established to build social media and online communities are Youtube, Google, Instagram, Amazon, Apple, Twitter and many others and as such, enterprises and individuals engage in social and economic exchanges and transactions via the aforementioned digital and social media platforms (Bowen, Green and James, 2008; Cunningham, 2015; Jain and Schultz, 2016; Helmond, Nieborg and Van der Vlist, 2019).

Social media platforms as technological driven processes that facilitate communication, they have become embedded in human existence and the use of social media platforms is dominant in diverse fields and sectors of the global economy. In promoting goods and services to prospects and customers, social media platform is an indispensable and strategic communication tool for marketing campaign (Chahine and Malhotra, 2018). As a consequence, Chahine et al, (2018) examine the impact of social media platform strategies on stock price using the case of twitter. The scholars conclude that a significant market reaction was found with the launching of twitter platform from firms and further assert that the use of twitter among stakeholders can add value to firms. Furthermore, Burton and Soboleva(2011) 
analysed the interactive or reactive communication with the use of twitter for marketing. The scholars conclude that twitter is another channel of communication that foster the access to information dissemination to organizational members and as well receive and respond to customers' complaints. In addition, Alzougool (2019) wrote on the use twitter and other five social media platforms by small and medium enterprises in Kuwait. The author averred that twitter, facebook, instagram and other platforms were applied by owner-managers of SMEs for marketing and exchange of information.

Facebook has increasingly become one of the prominent social media platforms for communication, entertainment, information sharing and networking. On a global scale, it has over 500 million active users with more than 30 billion snippets of content and 900 million objects of groups, events and community pages with which people interact ( Suki, Ramaya and Ly, 2012). They documented that the objects for using facebook platform are personal, friendly and business relations. Consequently, social relations, work-centric and daily related activities are the underlying cardinal purposes for the usage of facebook platform. In addition, facebook social media platform possesses the potentials for selling, advertising and marketing of products and services with minimum skill requirement, optimum and cost effective advantage. Business individuals and firms are encouraged to utilise the platform to stimulate performance of firms (Ainin, Parveen, Moghvvemi and Jaafar, 2015). In the context of micro entrepreneurs of agency banking firms in Nigeria, there is need to interrogate as to whether facebook platform is employed to communicate, collaborate and exchange resources for the purpose of improving firm performance.

Instagram as a social media platform has been utilized by different category of individuals and business entities. Linne (2016) studied the application of facebook and instagram social media accounts by firms in the Swedish diary industry to build producer-consumer relations. The author articulated that instagram accounts present idyllic graphic pages of cows for milk extraction by workers of firms with high sense of ethical matrix and promote ethical participation and consumption. The focus is to demonstrate diary and diary production in an ethically justifiable manner through the instagram platforms. In another study, Ye, Hashim, Baghirvo and Murphy (2017) evaluated gender differences in the instagram hastags use. It was established that females have the tendency to use more of emotional and positive hastags description of Malaysian foods. In addition, the authors documented that a positive relationship exist between the number of hastags used and the number followers. They concluded that a high satisfaction with Malaysian foods arises from the number of positive and negative hastags. The literature indicated that hastag as a function of instagram has the potential to facilitate the categorization of photos and expression of feelings. Due to this advantage, instgram is popularly used by business entities and individuals to create and promote brand awareness and management (Ye et al, 2017).

\subsection{Micro Entrepreneurial Networks}

The ancient and traditional means of connecting people, enterprises, states and nations across national boundaries have undergone revolution and highly accelerated due to the advent of digital technologies with inexpensive and powerful computers, high-capacity mobile and fixed communication infrastructure, digital platforms, social network and networking on the web (Strokes, Wilson and Mador, 2010). A network is simply conceptualized as a collection of connected points; the points are referred to as nodes while the connections are ties. Further, the nodes signify actors who are individuals, teams, institutions and organizations as against the ties which depict binary social relations (Wineman, Kabo and Davis, 2009; Strokes, Wilson and Mador, 2010). 
Albeit network is of a technical and science foundation, the extension of network into the social science scholarship and application originates from the seminal work of Mitchell (1969) who theorizes that society is composed of networks that represent social relations and interactions of individuals and organizations. Granovetter (1985) draws on the social network theory and argues that economic action is embedded in the network of social relations to create meaning and value. Hence, social network theory has attracted scholarly attention and becomes ubiquitous in entrepreneurship, economic and business sciences (Anderson, Jack, Dodd, 2005; Hampton, Cooper and McGowan, 2009; Masrello and Izzo, 2019; Nikiforou, Lioukas \& Voudouris, 2020).

In the dimension of business, Network means "sets of two or more interconnected exchange relationship" (Axelsson and Easton, 1992: 365). A business organization is a network of individuals while an economy is a network of organizations and individuals. Business and social networks are sets of actors who are individuals and organizations with ties and linkages providing channels for critical information and resources interchange. Accordingly, entrepreneurial performance and success is enhanced or inhibited by social networks (Fernandez-Perez, Alonso-Galicia, Fuentes-Feuntes and Rodriguez-Ariza, 2014). Entrepreneurs are with high propensity to engage and work by and through other people to explore, identify, recognize and exploit business opportunities, acquire resources, organize markets, manage suppliers and customers, investigate the business environment and formulate and translate strategies into action (Casson and Giusta, 2007; Brundel, 2006; Bastian and Zali, 2016; Ahmad and Dimitrato, 2017). The gradual process of entrepreneurs to develop set of relationships with other individuals and enterprises over time and space with a view to identifying and exploiting opportunities, accessing resources, generating and exchanging knowledge and innovative ideas is entrepreneurial networking (Ahmad and Dimitrato, 2017; Anderson, Jack and Dodd, 2005).

Entrepreneurial networks fall under diverse rubrics as presented by scholars but majorly, these categories are pigeonholed into informal and formal social networks which are otherwise referred to as personal social network and inter-organizational networks respectively. Personal social network is comprised of family relatives, friends, employees, previous employers and others while inter-organisational network is composed of organizations and individuals (Hanson and Blake, 2009; Skokic, Lynch and Morrison, 2019; Strokes, Wilson and Mador, 2010).

Social relations and network structure are dynamic with respect to density, size and strength. Strong social ties are born out of natural phenomenon, and such entrepreneurial ties are established through personal-private connections with people of common focus, background and experience. Accordingly, strong social relations minimizes risk and uncertainty associated with opportunism due to trust existing in strong social ties while weak social relations consist of professional and individual ties which are impersonal and distant individuals with high risk of opportunism. However weak social ties pave way for innovations and novel business opportunity recognition. Therefore, micro entrepreneurs of agent banks can take advantage of social media platforms to network with customers and associates as opposed to the traditional networking through face to face contact (Jack, Dodd and Anderson, 2009; Batstian and Zali, 2016; Urban, 2019). 


\section{Theory and Hypothesis Development}

\subsection{Social media platforms for micro entrepreneurial networking and performance of agent banking firms}

A good number of measures have been applied to asses business and firm performance. In the case of agent banking firms, performance metrics is examined on the basis of volume of money flow, number of transactions in a specific period, rate of turnover, cost effectiveness in communication and marketing performance in relation to number of customers in a given time frame. Among the aforementioned performance indices, volume of transaction, turnover and number of customers have been affirmed as performance measures of agent banks (Margaret and Ruth, 2019). The concern is how micro entrepreneurs of agent banks utilize facebook, instagram, twitter and other digital platforms to network with formal and informal ties to stimulate financial intermediation and increase performance level in Nigeria.

In the study of Li, He and Zhang (2019), the link between social media information accessing and business performance was established by investigating small businesses in China. The findings demonstrated that information over government and industry policies impacted business performance while gender and education of entrepreneurs moderated the effects of information on business performance. Furthermore, Berger and Thomas (2016) investigated SMEs- social media marketing performance and underscored the need for monitoring marketing performance of SMEs through the use of social media. The scholars conclude that monitoring of SME-social media performance is not a common practice but the focus is perceived cost and time elements involved in the process.

Ainim, Parveen, Moghavvemi and Jaafer (2018) postulated that the use of facebook by SMEs stimulated financial and non-financial performance outcomes essentially due to the cost reduction on marketing, customer service, improved customer relations and information accessibility. The scholars underscored the importance of social media platforms as a means to foster networking and exchange critical resources among SMEs and stakeholders. The cost reduction with marketing of products is a substantial competitive edge for firms to thrive in the market space. Further, Odoom, Anning-Dorson and Acheampong (2017) examined the motivation for the use social media platforms and the attendant performance benefits. The authors reported interactivity, cost effectiveness and compatibility as motivating factors to utilize social media platforms which have positive effect on product-based and service-based SMEs performance.

It has been articulated that corporate image management through social media platforms enhance financial performance of firms (Schenierderjan, Coa and Schenierderjan, 2013). From the perspectives of the scholars, social media as a tool for impression management of corporate image reinforces the communication strength of internal and external stakeholders and concluded that social media usage facilitates impression management strategies to positively contribute, in part, to firm financial performance.

Rodriguez, Peterson and Krishnan (2012) investigate social media influence on business to business sales performance. Specifically, the article focuses on the use of linkedIn, twitter and sales performance at the firm to firm level. They reported that there was a positive relationship between media sales process of creating opportunities and relationship management and sales performance. Consequent upon the theoretical development of the literature, the following research questions and hypotheses are considered. 
Do micro entrepreneurs of agent banking firms utilize social media platforms to establish formal and informal business ties?

Does the performance level of agent banking firms improve for utilizing social media platforms?

\section{$H_{0}:$ The use digital media platforms for entrepreneurial networking do not have significant effect on the performance rate of agent banking firms}

\section{$\mathrm{HO}_{2}$ There is no significant difference in the performance level of agent banking firms with respect to the use of various social media platforms}

\section{Methodology}

The study applied analytic descriptive survey design and data were collected from a sample of 150 micro entrepreneurs of agent banking firms across Yenagoa metropolis in Bayelsa State of Nigeria.

Cluster sampling involves the selection of clusters as against individual sampling units and subsequently adopts simple random sampling procedure in selecting the individual units from the previously selected clusters which normally consist of naturally occurring groups and geographic boundaries (Singh, 2007). Following the naturally established twenty group of communities with geographic demarcations in the Bayelsa State capital, cluster sampling strategy was applied in selecting the sample, and by a two-stage sampling approach, simple random sampling was also used by first selecting 10 from a total 20 towns as clusters in the cosmopolitan city of Yenagoa. The clusters of the towns selected were Agudama-Epie, Azikoro, Biogolo, Kpansia, Opolo, Amarata, Akenfa, Ovom, Swali and Okaka. Thus, the sampling units of 15 micro entrepreneur agents of banking firms were selected from each of the 10 clusters of towns yielding a total sample 150 bank agents.

The method for data collection was self administered and self reported questionnaire to micro entrepreneur agents of banks. The questionnaire consists of 8 items in categorical structure was designed in dichotomous form of "yes" or "no", multinomial structure with respect to forms of social media platforms of facebook, instagram, twitter and other platforms, a 3-point Likert scale of agree, disagree and undecided with respect to performance dimensions while the overall rate of performance was designed in rank order which is ordinal measurement level of low, moderate and high. The instrument was meant to elicit responses in view of use of social media platforms, use of social media platforms to establish formal and informal ties for business purposes and the level of performance of the respective agent banks attributable to social media networking.

For the dichotomous questionnaire items, it was coded as "Yes $=1$ ", "No $=0$ "; multinomial item is coded as "Facebook $=1$ ", "Instagram $=2$ ", "Twitter $=3$ ", "others $=4 " ; 3$ point Likert scale was disagree $=1$, undecided $=2$, agree $=3$; while rate of performance item was coded "Low =1", "Moderate= 2", and "High = 3" The coding of the instrument was to facilitate the use of Statistical Package for Social Science (SPSS) Version 20.

The data collected were analysed by the application of frequency counts, percentage distribution. At the inferential level, Analysis of Variance and ordinal logistic regression were applied for the test of hypotheses. The ranking of performance in agent banking firms is the response (dependent) variable while the social media platforms are the predictors (independent variables) with regard to the ordinal logistic regression. The performance 
questionnaire item is with ordered categories which require the use of ordinal logistic regression with maximum likelihood estimation method (Agresta, 2013). Moreover, One Way Analysis of Variance (ANOVA) was applied to determine as to whether there is difference in performance level of agent banks with respect to the most frequently used social media platforms for networking.

\section{Data Analysis and Results}

This segment concerns with the presentation of analysed data, interpretation and discussion of results in line with previous studies.

Research question one: Do micro entrepreneurs of agent banking firms utilize social media platforms to establish formal and informal business ties?

Tabel 1: Most Often Used Platform by Micropreneurs of Agent Banking Firms for Networking

\begin{tabular}{|l|r|r|r|r|}
\hline & Frequency & Percent & $\begin{array}{c}\text { Valid } \\
\text { Percent }\end{array}$ & $\begin{array}{c}\text { Cumulative } \\
\text { Percent }\end{array}$ \\
\hline Facebook & 31 & 20.7 & 20.7 & 20.7 \\
Instagram & 52 & 34.7 & 34.7 & 55.3 \\
Valid Twitter & 39 & 26.0 & 26.0 & 81.3 \\
Others & 28 & 18.7 & 18.7 & 100.0 \\
Total & 150 & 100.0 & 100.0 & \\
\hline
\end{tabular}

Source: SPSS Computation Output, 2020

Table 1 above demonstrates frequency and percentage distribution of digital platforms frequently used by micro entrepreneurs of agent banking firms to strike network relationships in Yenagoa metropolis. The responses indicated that $31(20.7 \%)$ of the entrepreneurs utilizes facebook, $52(34.7 \%)$ of micro entrepreneurs uses instagram, 39(26\%) applies twitter while $28(18.7 \%)$ uses other forms of social media for networking. From all the responses, it implies that instagram is the most often used digital platform among the micro entrepreneurs.

Table 2: Use of Social Media Platforms by Micropreneurs of Agent Banking Firms to Establish Informal Ties for Business Purpose

\begin{tabular}{|c|r|r|r|r|}
\hline & Frequency & Percent & $\begin{array}{c}\text { Valid } \\
\text { Percent }\end{array}$ & $\begin{array}{c}\text { Cumulative } \\
\text { Percent }\end{array}$ \\
\hline Yes & 83 & 55.3 & 55.3 & 55.3 \\
Valid No & 67 & 44.7 & 44.7 & 100.0 \\
Total & 150 & 100.0 & 100.0 & \\
\hline
\end{tabular}

Source: SPSS Computation Output, 2020.

As shown in table 2 above, it is a frequency and percentage distribution on the use of social media platforms by micro entrepreneurs to initiate informal ties for business purposes in 
Yenagoa metropolis. The responses demonstrate that $83(55.3 \%)$ of the micro entrepreneurs of agent banking firms establish informal ties with respect to their business needs as opposed to $67(44.7 \%)$ of micro entrepreneurs who responded in the negative, indicating that they do not use social media platforms to form informal ties in view of their businesses. From all the responses, it implies that a sizeable number of micro entrepreneurs do not network with friends and family member specifically for business exigencies.

Table 3: Use of Social Media Platforms by Micro Entrepreneurs of Agent Banking Firms to Establish Formal Ties for Business Purpose

\begin{tabular}{|c|r|r|r|r|}
\hline & Frequency & Percent & $\begin{array}{c}\text { Valid } \\
\text { Percent }\end{array}$ & $\begin{array}{c}\text { Cumulative } \\
\text { Percent }\end{array}$ \\
\hline Valid No & 78 & 52.0 & 52.0 & 52.0 \\
Total & 72 & 48.0 & 48.0 & 100.0 \\
\hline
\end{tabular}

Source: SPSS Computation Output, 2020

As shown in table 3 above, it is a frequency and percentage distribution on the use of social media platforms by micro entrepreneurs to initiate formal ties for business purposes in Yenagoa metropolis. The responses demonstrate that $78(52 \%)$ of the entrepreneurs of agent banking firms establish formal ties with respect to their business needs as against $72(48 \%)$ of micro entrepreneurs who responded in the negative, indicating that they do not use social media platforms to establish formal ties in view of their businesses.

Research question Two: Does the performance level of agent banking firms improved for utilizing social media platforms?

Table 4: The use of social media for networking improves volume of transactions of agent banking firms

\begin{tabular}{|c|c|c|c|c|c|}
\hline & & Frequency & Percent & Valid Percent & $\begin{array}{c}\text { Cumulative } \\
\text { Percent }\end{array}$ \\
\hline \multirow{4}{*}{ Valid } & Disagree & 23 & 15.3 & 15.3 & 15.3 \\
\hline & Undecided & 18 & 12.0 & 12.0 & 27.3 \\
\hline & Agree & 109 & 72.7 & 72.7 & 100.0 \\
\hline & Total & 150 & 100.0 & 100.0 & \\
\hline
\end{tabular}

Source: SPSS Computation Output, 2020

In table 4 above, 109(72.7\%) of micro entrepreneurs of agent banks affirmed that the use of social media platforms for networking improves the volume of transactions while only $23(15.3 \%)$ disagreed, stating that networking through the use of social media platforms never improved the amount of transactions in their firms. However, 18(12\%) of the micro entrepreneurs were non committal to the statement as to whether use of social media for networking improves volume of agent bank transactions. 
Table 5: Use of social media for networking enhances rate of turnover of agent banking firms

\begin{tabular}{|c|c|c|c|c|c|}
\hline & & Frequency & Percent & Valid Percent & $\begin{array}{c}\text { Cumulative } \\
\text { Percent }\end{array}$ \\
\hline \multirow{4}{*}{ Valid } & Disagree & 30 & 20.0 & 20.0 & 20.0 \\
\hline & Undecided & 22 & 14.7 & 14.7 & 34.7 \\
\hline & Agree & 98 & 65.3 & 65.3 & 100.0 \\
\hline & Total & 150 & 100.0 & 100.0 & \\
\hline
\end{tabular}

Source: SPSS Computation Output, 2020

As shown in table 5 above, 98(65.3\%) of micro entrepreneurs of agent banks agreed that the use of social media platforms for networking enhances the rate of turnover while only $30(20 \%)$ disagreed, indicating that networking through the use of social media platforms did not enhance the rate of turnover of their firms. However, 22(14.7\%) of the micro entrepreneurs did not express their position whether use of social media for networking stimulate the rate of turnover of agent bank.

Table 6: Use of social media for networking has increased your customer base of agent banking firms

\begin{tabular}{|c|c|c|c|c|c|}
\hline & & Frequency & Percent & Valid Percent & $\begin{array}{c}\text { Cumulative } \\
\text { Percent }\end{array}$ \\
\hline \multirow{4}{*}{ Valid } & Disagree & 26 & 17.3 & 17.3 & 17.3 \\
\hline & Undecided & 16 & 10.7 & 10.7 & 28.0 \\
\hline & Agree & 108 & 72.0 & 72.0 & 100.0 \\
\hline & Total & 150 & 100.0 & 100.0 & \\
\hline
\end{tabular}

Source: SPSS Computation Output, 2020

As shown in table 6 above, 108(72\%) of micro entrepreneurs of agent banks affirmed that the use of social media platforms for networking expands the customer base while only $26(17.3 \%)$ disagreed, indicating that networking through the use of social media platforms did not lead to increase customers of their firms. However, $16(10.7 \%)$ of the micro entrepreneurs were indifferent to the statement of use of social media for networking increase the number of customers of agent banks.

Table 7: Use of social media for networking improves operational efficiency of agent banking firms

\begin{tabular}{|c|c|c|c|c|c|}
\hline & & Frequency & Percent & Valid Percent & $\begin{array}{c}\text { Cumulative } \\
\text { Percent }\end{array}$ \\
\hline \multirow{4}{*}{ Valid } & Disagree & 28 & 18.7 & 18.7 & 18.7 \\
\hline & Undecided & 11 & 7.3 & 7.3 & 26.0 \\
\hline & Agree & 111 & 74.0 & 74.0 & 100.0 \\
\hline & Total & 150 & 100.0 & 100.0 & \\
\hline
\end{tabular}

Source: SPSS Computation Output, 2020 
From table 7 above, 111(74\%) of micro entrepreneurs of agent banks affirmed that the use of social media platforms for networking improves operational efficiency while only $28(18.7 \%)$ percent disagreed, indicating that networking through the use of social media platforms does not improve the operational efficiency of agent banking firms. However, 11(7.3\%) of the micro entrepreneurs were indifferent to the statement of use of social media for networking increase the operational efficiency of agent banks.

Table 8 :The overall performance rate of agent banking firms with the use of social media platforms for networking

\begin{tabular}{|c|c|c|c|c|c|}
\hline & & Frequency & Percent & $\begin{array}{c}\text { Valid } \\
\text { Percent }\end{array}$ & $\begin{array}{c}\text { Cumulative } \\
\text { Percent }\end{array}$ \\
\hline \multirow{4}{*}{ Valid } & Low & 54 & 36.0 & 36.0 & 36.0 \\
\hline & Moderate & 69 & 46.0 & 46.0 & 82.0 \\
\hline & High & 27 & 18.0 & 18.0 & 100.0 \\
\hline & Total & 150 & 100.0 & 100.0 & \\
\hline
\end{tabular}

Source: SPSS Computation Output, 2020

Table 8 shows the frequency and percentage distribution of the overall rate of performance of agent banking firms attributable to the use of social media platforms for formal and informal networking with relations, associates and other firms. The rating demonstrates that $54(36 \%)$ of agent banking firms' performance is low, 69(46\%) of the firms is moderate and only $27(18 \%)$ of the firms is high performance due to the utilization of social media platforms. From all the responses, it suggests that a predominant number of agent banking firms owned by micro entrepreneurs do not have high but moderate level of performance considering the use of digital media for entrepreneurial networking.

\section{Hypothesis}

$H_{0}$ : The use digital media platforms for entrepreneurial networking do not have significant effect on the performance rate of agent banking firms

$H_{a}:$ The use digital media platforms for entrepreneurial networking do not have significant effect on the performance rate of agent banking firms 
Table 9: Ordinal Logistic Regression Analysis of Digital Media Platforms on the Performance Rate of Agent Banking Firms

Parameter Estimates

\begin{tabular}{|c|c|c|c|c|c|c|c|c|}
\hline & \multirow[t]{2}{*}{$\begin{array}{c}\text { Estimate } \\
B\end{array}$} & \multirow[t]{2}{*}{$\begin{array}{l}\text { Std. } \\
\text { Error }\end{array}$} & \multirow[t]{2}{*}{$\begin{array}{l}\text { Wald } \\
X^{2}\end{array}$} & \multirow[t]{2}{*}{$D f$} & \multirow[t]{2}{*}{ Sig. } & \multicolumn{2}{|c|}{$\begin{array}{c}95 \% \text { Confidence } \\
\text { Interval }\end{array}$} \\
\hline & & & & & & & $\begin{array}{l}\text { Lower } \\
\text { Bound }\end{array}$ & $\begin{array}{l}\text { Upper } \\
\text { Bound }\end{array}$ \\
\hline \multirow[b]{2}{*}{ Threshold } & {$[$ Low Performance $=1.00]$} & -.708 & .365 & 3.768 & 1 & .052 & -1.423 & .007 \\
\hline & $\begin{array}{l}\text { [Moderate Performance }= \\
2.00]\end{array}$ & 1.411 & .382 & & 1 & .000 & 663 & 2.160 \\
\hline \multirow{4}{*}{ Location } & [Facebook Platform=1.00] & .445 & .493 & .815 & 1 & .367 & -1.410 & .521 \\
\hline & [Instagram Platform $=2.00$ ] & 147 & 440 & .112 & 1 & .738 & -.716 & 1.011 \\
\hline & [Twitter Platform=3.00] & .331 & 467 & .503 & 1 & .478 & -1.246 & .584 \\
\hline & [Other Platforms $=4.00$ ] & $0^{\mathrm{a}}$ & & & 0 & & & \\
\hline
\end{tabular}

Link function: Logit.

a. This parameter is set to zero because it is redundant.

Note: Pseudo $\mathrm{R}^{2}=0.02$ (Cox \& Snell), 0.02 (Nagellkerke), 0.01(McFadden); Model $\mathrm{X}^{2}(3)$ $=2.52, P>0.05,-2 L L^{a}=30.37$; B: Beta co-efficient (Estimates), SE: Standard Error, df: degrees of freedom, $-2 L L^{a}$ : -2 Log Likelihood

From table 9, the results demonstrate that the use of social media platforms of facebook, instgram, twitter and other platforms for entrepreneurial networking on the whole do not have significant effect on the rate of performance of agent banking firms ( Wald $\mathrm{X}^{2}=2.52$, $\mathrm{df}=3, \mathrm{p}>0.05$ ). This means that the model is not a good predictor. In consideration of the Cox \& Snell $R^{2}=0.02$, it shows that only $2 \%$ of the variance of the rate of performance is accounted for and explained by the predictors. In the partition of location and the individual categories of facebook, instagram, twitter and other platforms, the respective co-efficient, standard errors and $\mathrm{X}^{2}$ and the significant values (Probability values) are presented. The coefficients for the platforms such as facebook $\beta=.45$, instagram $\beta=.15$, twitter $\beta=.33$ and Wald $X^{2}=.83, p>0.05$, Wald $X^{2}=.12, p>0.05$, Wald $X^{2}=.32, p>0.05$. The respective contributions of the coefficients, wald test statistics and probability values indicated that each platform does not have significant effect on the performance level of agent banking firms. The coefficients of the platforms are positive, suggesting that the increase in the use of digital platforms for entrepreneurial networking gives rise to increase with respect to the performance rate of agent banking firms. The individual coefficients indicated that facebook as a predictor has the predominant contribution of $45 \%$ while instagram as a predictor has the least contribution of $15 \%$ to the level of performance of agent banking firms in regard to the use of social media platforms for networking. Since the use of social media platforms on the whole do not have significant effect on the performance rate of agent banking firms (Wald $\mathrm{X}^{2}$ $=2.52, \mathrm{df}=3, \mathrm{p}>0.05)$. Thus, the null hypothesis is not rejected.

$\mathrm{HO}_{2}$ There is no significant difference in the rate of performance of agent banking firms with respect to the use social media platforms

$\mathrm{Ha}_{2}$ There is a significant difference in the rate of performance of agent banking firms with respect to the use social media platforms 
Table 10: Descriptive Statistics on the rate the performance Agent banking firms and use of different social media platform

\begin{tabular}{|ll|r|r|r|r|r|}
\hline & & Facebook & $\begin{array}{r}\text { Instagra } \\
\mathrm{m}\end{array}$ & Twitter & Others & \multicolumn{1}{c|}{ Total } \\
\hline $\mathrm{N}$ & & 31 & 52 & 39 & 28 & 150 \\
Mean & 1.7097 & 1.9231 & 1.7436 & 1.8571 & 1.8200 \\
Std. Deviation & & .73908 & .73688 & .71517 & .65060 & .71485 \\
Std. Error & .13274 & .10219 & .11452 & .12295 & .05837 \\
& & & & & \\
$95 \%$ Confidence & Bound & 1.4386 & 1.7179 & 1.5118 & 1.6049 & 1.7047 \\
Interval for Mean & Upper & 1.9808 & 2.1282 & 1.9754 & 2.1094 & 1.9353 \\
& Bound & 1.00 & 1.00 & 1.00 & 1.00 & 1.00 \\
Minimum & & 3.00 & 3.00 & 3.00 & 3.00 & 3.00 \\
Maximum & & & & & &
\end{tabular}

Source: SPSS windows output, 2020

\section{ANOVA}

Table 11:F Test on the performance rate of Agent Banking Firms and Use of different social media platforms for networking

\begin{tabular}{|l|r|r|r|c|c|}
\hline & $\begin{array}{c}\text { Sum of } \\
\text { Squares }\end{array}$ & Df & $\begin{array}{c}\text { Mean } \\
\text { Square }\end{array}$ & F & Sig. \\
\hline Between Groups & 1.196 & 3 & .399 & .777 & .509 \\
Within Groups & 74.944 & 146 & .513 & & \\
Total & 76.140 & 149 & & & \\
\hline
\end{tabular}

Source: SPSS windows output, 2020

Table 10 displays the descriptive statistics over the performance rate of agent banking firms in connection with the use of different social media platforms. The focus is to determine the difference in performance level arising from the use of social media platforms of facebook, instagram, twitter and other category of platforms. From the result, the mean value for facebook is 1.7, instagram 1.9, twitter 1.7 and others 1.8. By careful observation, the mean value of instagram is highest while facebook is the least. This shows that there is a difference in the performance level of agent banking firms with respect to the use of social media platforms of facebook, instagram, twitter and others. Considering whether there is a statistically significant difference in the performance rate of the agent banks due to the use of social media platform, table 11 is presented with the Analysis of Various (ANOVA). The result shows that there is no significant difference in the performance level of agent banking firms among the social media platforms $(\mathrm{F}(3,146)=.78, \mathrm{p}>0.05)$. Thus, the null hypothesis is rejected.

\section{Discussion, Conclusions and Entrepreneurial contributions}

Results from the study indicated that agent banking firms utilize social media platforms to initiate informal ties to access critical resources to improve their business performance. The finding lends credence to the assertion of Jarrahi (2017) that social media platforms play a 
significant role in knowledge sharing among colleagues and workers within and across organizations. However, some of the micro entrepreneurs of agent banks network with family acquaintances and kinship, but the networking is not exclusively for business transactions. Drawing on the use of social media to establish formal ties by micro entrepreneurs to exchange resources, the finding suggests that a large number of micro entrepreneur bank agents do network with business associates and entities specifically for business transactions. The finding of the current study concurs with the previous work of O'Connor (2011) who examined the use of facebook as a social media platform by international hotel chains and found that facebook was effectively exploited as a means of communication and making sales to customers by hotel chains.

The results from the analysis demonstrated that most of the firms is ranked moderate in business performance while an insignificant number of the firms attained high performance level due to the utilization of social media platforms. From all the results, it suggests that a predominant number of agent banking firms owned by micro entrepreneurs do not have high level of performance in association with the use of digital media for entrepreneurial networking. This presupposes that micro entrepreneurs of bank agents require exposure to adequately explore the application of social media platforms and direct their energies positively to networking with business associates and relatives to advance and intensify the performance rate in the financial service industry. The Cox \& Snell $R^{2}$ affirmed that only $2 \%$ of the variance of performance level was accounted for and explained by the predictors, which demonstrated further that $87 \%$ of the performance of agent banks was accounted for by other predictors that were not included this model. The Wald test was not significant at the individual predictors and as well as the aggregate Wald test. Nonetheless, the individual coefficients demonstrated positive contributions, suggesting that the predictors had positive effect on the performance of agent banking firms. The current finding of the study that social media platforms had effect on the performance of agent banks underpins the previous research findings of Quiton and Wilson(2016) that the social media platform of LinkedIn enhanced business performance through networking to build social, transactional and relational ties.

Considering whether there is a statistically significant difference in the performance rate of the agent banks due to the use of social media platform, the result showed that there was no significant difference in the performance level of agent banking firms with respect to use of the social media platforms. The result of the current research underpins the previous empirical evidence of Jussila, Karkkainem, Aramo-Immonen(2014) who studied social media utilization in business to business relationship of technology firms, and attempted to examine the differences in the external use of social media on the bases of firm size characteristics of sales turnover and number of employees. The results demonstrated that there was no significant difference in the external use of social media with respect to firm size of sales turnover and employee size respectively. Albeit the current study focuses on the performance difference of agent banks arising from the use of diverse social media platforms such as facebook, twitter, instagram and as independent factors that could influence the performance variation, the previous study centered on the differences of the external use of social media as to whether firm size characteristics of sales turnover and workforce were determinants to the diversity in external use of social media.

Based on the findings of the study, the paper concludes that micro entrepreneur agents of banking firms do network with social media platforms but some of bank agents do not 
network with a view to establishing formal and informal ties for business purposes. Further, the use of social media platforms brought about moderate performance of agency banking firms. Social media platforms had positive effect on the level of performance of agency banking firms in Nigeria. There was a difference but insufficient variation at the performance level of agent banking firms with respect to the use of social media platforms.

The study has established significant findings and made enormous contributions to entrepreneurial practice and theoretical development. Drawing on the finding that micro entrepreneurs of agent banks utilize social media platforms to network with kinship and business associates, micro entrepreneurs are encouraged to make the most of social media to establish ties within Nigeria and African continent to exchange novel and innovative ideas and information to exploit entrepreneurial opportunities, enhance performance in agency banking and other related entrepreneurial ventures. As argued by Leskinen (2011) that female entrepreneurial networking explores new channels, opportunities, products, contacts and employs available resources. With the cost affordance of social media networking, the finding contributed to entrepreneurial practice and theory by providing the associated benefits with social media platforms and networking with close and distant business associates and relations.

Furthermore, micro entrepreneurs of agent banking firms recorded moderate and high performance level consequent upon the use of social media network with existing customers and prospects. Based on the hypothesis postulated, social media platforms contributed to the performance level of agent banks attributable to networking through social media platforms. The finding lends credence to the research evidence of Laskinen (2011), Drummond, McGrath, O'Toole (2018) that entrepreneurial success is established through networking, stating that sales growth, profitability, efficiency, cost effectiveness, resource mobilization, targeting and identifying business partners as benefits that accrue to entrepreneurs. This finding contributes to entrepreneurial practice and theory that the characteristics of the entrepreneur alone are not responsible for entrepreneurs' performance but social media platforms for networking makes sustainable and substantial entrepreneurship success.

\section{Limitation and Direction for further studies}

The study was restricted to Yenagoa, the capital of Bayelsa State, Nigeria. This requires caution in making generalization of the findings across other regions of the country. As a consequence, further studies are to be conducted and replicated in other parts of the country.

\section{Acknowledgements}

We are grateful to the research subjects who responded to questionnaire items and the authors whose works were consulted in the study.

\section{Declaration Conflict of Interest}

The authors hereby declare that there is no potential conflict of interest to the authorship and publication to the article. 


\section{REFERENCES}

Abdulmumin, A. B; Etudaiye-Muhtav, F. O; Jimoh, T. A. and Sakariyahu, R. O. (2019), An investigation into financial inclusion in Sub-Saharan Africa, Scientific Annals of Economic and Business, Vol.66, No. 1. pp. 41-63

Agresta, A. (2013), Categorical data analysis, John Wiley \& Sons, New Jersey.

Ahmadi, S.and Dimitrato, P. (2017), "International entrepreneurship and networks", in Ahmeto, G., Champrro-Premuzic, T., Klinger, B. \&Karcisky, T. (eds). The Wiley handbook of entrepreneurship ( $1^{\text {st }}$ ed.) PP. 451-483.

Ainir, S., Parveen, F., Mogharvemi and Jaafar, N. I. (2015), "Factors influencing the use of social media by SMEs and its performance outcomes", Industrial Management and Data System, Vol. 115. No 3, 570-588.

Alzougoool, B. (2019), "The use of and continuance use of social media application by small and medium enterprises in Kuwait", Global Knowledge, Memory and Communication Vol. 68 No. 6/7, pp 471-490.

Anderson, R.A., Jack, L.S. and Dodd, D.S. (2005), "The role of family members in entrepreneurial networks: Beyond the boundaries of the family firm", Family Business ReviewXVIII(2); 135-154

Axelsson, B. and Easton, G. (Eds). (1992), Industrial networks: A new view of reality. Routledge, London

Ayenagbo. K, Rongcheng. W, wenging.W, Nguchi S., Kimatu J and Patrick J. M. C. (2013), "The impact of globalization on African Countries economic development", African Journal of Business Management Vol. 6 No.44, pp.11057-11075

Bastian, B. and Zali, R.M. (2016), "The impact of institutional quality on social networks and performance of entrepreneurs", Small Enterprise Research, Vol. 23 No.2, pp. 151-171.

Berger, H. and Thomas, C. (2016). "SMEs-social media marketing performance", International Journal of Web Engineering and Technology, Vol.11, No. 3, pp215-232

Bleaey, M. and Neaves, S.A. (2013), "Declining distance effects in international trade: some country level evidence", The World Economy Doi: 1011111twec.12034 PP.10291040

Brundel, R. (2006), "Managing "collisions" between entrepreneurial networks and industrial supply chains, a modified Penrosian perspective", International Journal of Management Concepts and Philosophy, Vol. 2 No.1, pp. 82-97.

Bowen, D.L., Green, A. and James, C. (2008), "Globalization, mobile phones and forbidden romance in Morocco", The Journal of North African Studies, Vol.13 No.2, pp. 227-241.

Burton, S. and Sobolera, A. (2011), "Interactive or reactive? Marketing with twitter", Journal of Consumer Marketing, Vol. 28 No. 6, pp. 491-499. 
Casson, M. and Giusta, D.M. (2007), "Entrepreneurship and social capital: Analyzing the impact of social networks on entrepreneurial activity from a regional action perspective”, International Small Business Journal, Vol. 25 No. 3, pp. 220-244.

Central bank of Nigeria[CBN] (2017), "Annual report, financial inclusion strategy implementation," Abuja: CBN

Central bank of Nigeria[CBN] (2013), "Financial inclusion in Nigeria: Issues and challenges," Abuja: CBN

Chahine, S. and Malhotra, N.K. (2018), "Impact of social media strategies on stock price: the case of twitter". European Journal of Marketing, Vol. 52 No. 718, pp.1526-1549.

Chen, F Fu L, Wang. K., Tsai, S. and Su, C. (2018), "The influence of entrepreneurship and social networks on economic growth- From a sustainable innovation perspective", Sustainable Vol.10 No.7, pp. 1-19

Christmann, P. and Taylor, G. (2002), "Globalization and the environment: strategies for international voluntary environmental initiatives", Academy of Management Executive Vol. 16 No.3, pp. 121-135.

Cunningham, S. (2015), “The new screen ecology: A new wave of media globalization"? Communication Research and Practice, Vol.1 No.3, pp. 275-282.

Das, M. and Goswami, N (2019). "Effects of entrepreneurial networks on small firm performance in Kamrup, a district of Assam", Journal of Entrepreneurship Research, Vol.9 No. 7 https://doi.og/10.1186/s 40497-018-01226

De Falco, E.S., Renzi, A., Orlando, B.and Cucari, N. (2017), "Open collaborative innovation and digital plat forms", Journal of Production \& Control Vol.20 No. 16, pp.13441353.

Dootson, P., Beatson, A., and Drennan, J. (2016), "Financial institutions using social mediado customers perceive value?", International Journal of Bank Marketing Vol. 34 No.1, pp 9-36

Drummond, C., McGrath, H. and O'Toole, T (2018), "The impact of social media on resources mobilization in entrepreneurial firms", Industrial Marketing Management, Vol.70, pp.68-89

Enhancing Finance Innovations \& Access (EFInA) ( 2018). EFInA Access to financial services in Nigeria, 2018 survey access 03 February, 2020 from Ukaid.

Fernandez-Pe'rez, V., Alonso- Galicia, P. E., Fementes-Fuentes, M and Rodriguez- Ariza, L (2014), "Business social networks and academics entrepreneurial intentions", Industrial Management \& Data Systems Vol.114 No.2, pp. 292-320 
Granovetter, M. (1985), "Economic action and social structure: The problem of embeddedness", American Journal of Sociology, Vol.91 No. 3, pp. 481 - 510.

Hampton, A. Cooper, S. and McGowan, P. (2009), "Female entrepreneurial networks and networking activity in technology based ventures: An exploratory study", International Small Business Journal, Vol. 27No.2, pp. 193-214.

Hanson, S. and Black, M. (2009), "Gender and entrepreneurial networks", Regional Studies, Vol.43 No.1, pp.135-149

Helmond, A., Nieborge, B. D. and Von derv list, N.F. (2019), Facebook's evolution: Development of platform as infrastructure, Journal of Internet Histories, Vol. 3 No. 2, pp. 123-146

Ibrahim, S.S; Odeser and Cavusoglu, B. (2018), "Financial inclusion as a pathway to welfare enhancement and income equality: Micro--level evidence from Nigeria, Development of Southern Africa, Doi. 10.108010376835x.2008.1498766

Jack, S., Dodd, D.S and Anderson, R.A. (2009), "Change and development of entrepreneurial networks over time: A processual perspective, Entrepreneurship and Regional Development", An International Journal, Vol. 20 No. 2, pp. 125-159.

Jarrahi, H. M (2017), "Social media and knowledge sharing in enterprise", IT Professional, Vol. 20 No.4, pp.37-45

Jain, V. and Schultz, E. D. (2016), "How digital platforms influence luxury purchase behaviour in India"? Journal of Marketing Communication, pp. 1-24.

Jussila, J. J., Karkkainen, H., and Aramolo-Immonen, H. (2014), "Social media utilization in business to business relationship of technology firms", Computers in Human Behaviour, Vol.30, pp.606-613

Kahar, R.; Yamimi, F., Bunari, G and Habil, H (2012), "Trusting the social media in small business", Procedia-Social and Behavioural Sciences Vol. 66, pp. 564-570

Leskinen, R. (2011), "Success in female entrepreneurial networking process", Annals of Innovation \& Entrepreneurship, Vol. 2 No.1, 6002, DOI: 10.3402/aiev2it6000

Li, X; He, X; and Zhang, Y. (2019), "The impact of social media on the business performace of small firms in China", Journal of Technology Development, 26(2), 346-368

Linne, T. (2016), "Cows on facebook and instagram: Interspecies intimacy in social media spaces of the Swedish diary industry", Television \& New Media Vol.17, No.8, pp. 719-733

Margaret G. K. and Ruth, K.N. (2019), "The effect of Banking Services on the business permanence of bank agents in Kenya", Cogent Business \& Management, Vol. 6 No. 1, pp. 684-420 
Masnello, B. and Izzo, F. (2019), "Interpersonal social networks and internationalization of traditional SMEs", Journal of Small Business Management, pp.1-34 doi.org/10.1111/jsbon. 12536

McCaan, M and Barlow, A (2015), "Use and measurement of social media for SMEs", Journal of Small Business and Enterprise Development, Vol. 22, No.2, pp. 273-287

Mitchell, J.C. (1969), "The concept and use of social networks, in Mitchell, J.C. (Ed). Social Networks in Urban situation, Manchester University Press, pp. 1-50.

Mukherjee, S (2018), "Challenges to Indian micro small scale and medium enterprises in the era of globalization", Journal of Global Entrepreneurship Research, Vol.8 No.28, pp. $1-19$

Napoleon cat.com(2019), Instagram users in Nigeria, Napoleon cat.com/statis/instagram users-in-Nigeria

Nikiforou, I.A., Lionkas, S and Voudouris, I.(2010), "Network structure and firm-level entrepreneurial behaviour, the role of market and technological knowledge networks", Journal of Business Research Vol.106, pp. 129-138.

National Bureau of Statistics[NBS] (2019), "Poverty and inequality in Nigeria" Abuja: NBS

O Conner, P. (2011), "An analysis of the use of facebook by international hotel chains", International CHRIE conference at the University of Massachueters. Amherest, https//: schelarworks.Umass. edu/refereed/CHRIE-2011/Wednesday/9

Odoom, R; Annin-Dorson, T and Acheampong, G. (2017), "Antecedents of social media usage and performance benefits on small and medium sized enterprise(SMEs)", Journal of Enterprise Management, Vol.3 No 3, pp.383-399

Ogunwusi, B. (2019, May 30), “Appraising Nigeria’s Agent Banking Policy”, Independent Newspaper, May 30.

Olanrewaju, T. A., Hossain, A. M., Whiteside, N. and Mercieca, P. (2020), " Social Media and entrepreneurship: A literature review", International Journal of Information Management Vol.59, pp. 90-110

Patricia - Nezianaya, N.C. and Izuchukwu, D.C. (2014), "Impact of agent banking on performance of deposit money banking in Nigeria", Research Journal of Finance and Accounting, Vol. 5 No. 9, pp. 35-40.

Petrova, K .(2013), "The effects of globalization on entrepreneurship", International Advances in Economic Research, Vol. 5, pp.1-3

Quinton, S and Wilson, D (2016), "Tensions and ties in social media networks: Towards a model of understanding business relationship development business performance 
enhancement through the use LinkendIn", Industrial Marketing Management $x x x$, $x x x-x x x$

Reuver, M., Sorensen, C., and Basole, R. (2018), "The digital platform: a research agenda", Journal of Information Technology, Vol. 33, pp. 124-135

Rodridguez, M., Peterson, M. R. and Krishnan, V (2012), "Social media influence on business to business sales performance", Journal of Personal Selling \& Sales Management, Vol. 3 No. 3, pp. 365-378

Sahayim, A; Datta, A. and Brooks, S(2019), "Crowdfunding success through social media: Goining beyond entrepreneurial orientation in the context of small and medium sized enterprise", Journal of Business Research (in press).

Schnierderjan, D., Cao, E. S, and Schnierderjan, M (2013), "Enhancing financial performance with social media: An impression management perspectives", Decision Support Systems, Vol. 55 No. 4, pp. 911-918

Singh, K. (2007), Quantitative social research methods, Sage Publications, Los Angeles

Skokic, V., Lynch, P. and Morrison A. (2019), "Veza: An informal network of tourism entrepreneur", Annals of Tourism Research, Vol. 77, pp. 26-27.

Smith, C., Smith, B. and Shaw, E (2017), "Embracing digital networks: Entrepreneurs'social capital online", Journal of Business Venturing Vol. 32, No. 1. pp. 18-34

Statistica (2020) Number of facebook users in Nigeria, Statista. Com/statistics/972927

Steiner, A. (2014), "The globalization process and the Eastern bloc countries in the 1970s and 1980s", European Review of History: Revue europeenned'histoire, Vol. 21 No. 2, pp. 165-181.

Strokes, D., Welson, N. and Mador, M. (2010), Entrepreneurship, South- Western Cengage Learning, Australia.

Suku, N.M; Ramaya, T. and Ly, K. K. (2012), "Empirical investigation on factors influencing the behavioural intention to use facebook". Universal Access in the information society Vol. 11 No. 2, pp. 223-231.

Urban, B. (2019), "Social networking and opportunity recognition: A focus on internationalization firms in South Africa", The Journal of Entrepreneurship, pp. 1-21 Doi: 10:1177/0971355719851907 Journals. Sagepub.com/homefjoc

Uzoma, B. A.; Aliemen, O. I; Oluriola, O. I \& Emena, U. O. (2016) Agent banking and financial inclusion: The Nigerian experience, Proceedings of $28^{\text {th }}$ international business management association conference, 9-10 November, Serville, Spain

Ving, T. and Kluijver. de J. (2007), "Does globalization impact entrepreneurship? Comparative study of country level indicators", University of Armsterdam, Netherlands. Sport Working papers on Information Systems 7 (8) 
Journal DOI: www.doi.org/10.46654/AJBED

Wikipedia(n.d) The Free Encyclopedia, https://en.wikipedia.org/wiki/Bayelsa_Stat

Wineman, D.J., Kabo, W.F and Davis, F. G. (2009), "Spatial and social networks in organizational innovation", Environment and Behaviour, Vol. 41 No. 3, pp. 427-442

Yan, X., Cao, D., Andrikopoulou, P., Yan, Z and Bass, T. (2020), "Online social network, media supervision and investment efficiency: An empirical examinination of Chinese listed firms", Technology Forecasting and Social Change Vol. 154, pp. 119-969

Ye, Z., Hashim, Z.N., Baghirov F and Murphy, J (2017). "Gender differences in instagram hastag use", Journal of Hospitality Marketing and Management, Vol.27 No. 4, pp.386404 